\title{
Role of toll-like receptor 6 in pathogenesis of mycosis fungoides
}

\author{
Ragaie SM $^{(1)}$,Shaker OG ${ }^{(2)}$,Mohamed MH ${ }^{(3)}$ and Fawzy MA ${ }^{(4)}$.
}

(1) Professor of Dermatology, Faculty of medicine Cairo university.

(2) Professor of Biochemistry, Faculty of medicine Cairo university.

(3) Lecturer of Dermatology, Andrology and STDs, Faculty of medicine Fayoum university.

(4) Department of Dermatology, Andrology and STDs, Faculty of medicine Fayoum university.

Corresponding author: prof. Talal A. Abd-ElRaheem

E-mail address: talasam@yahoo.com

Tel:01006600360

Fax: +2084636583

\section{ABSTRACT}

Toll-like receptors (TLRs) are transmembrane proteins that function as pattern-recognition receptors for the detection and response to microbial ligands. Toll-like receptors (TLRs) have been implicated in various dermatological diseases including cutaneous T-cell lymphoma (CTCL). The aim of work is to measure the tissue and serum expression of TLR6 in mycosis fungoides (MF) patients in comparison to age and sex matched healthy controls to investigate its role in pathogenesis in MF. This case-control study was carried out on 48 subjects. These included $33 \mathrm{MF}$ patients and 15 age and sex matched healthy volunteers served as controls. Tissue TLR6 expression was decreased in MF patients than in controls in highly statistically significant manner with $p$ $<0.001$ denoting the strong correlation between TLR6 and MF.
KEY WORDS: Toll-like receptors, Mycosis fungoides, Toll-like receptor 6

\section{INTRODUCTION}

Toll like receptors (TLRs) have been established to play an important role in activation of innate immune response by recognizing various microbial-derived molecules. They act as receptors for bacteria and fungi, and mediate the production of cytokines in response to a variety of viruses and viral ligands [1]. To date, 10 TLR family members have been identified in humans, and at least 13 are present in mice [2].

Cutaneous T-cell lymphoma (CTCL); is a lymphoprolifrative disorder characterized by clonal expansion of malignant CD4+ T cell in the skin [3]. Mycosis fungoides represents 
the most common form of primary cutaneous T-cell lymphoma (CTCL) [4].

TLRs and their pathways have been implicated in various dermatologic diseases including acne, atopic dermatitis, psoriasis, infectious diseases and CTCL [5].

Some studies revealed lower expression of TLR in MF as the study conducted by (Tawdy et al., 2017) which revealed lower TLR7 expression in MF patients in comparison to healthy controls. On the other side, there are studies that revealed increased expression of TLR in MF as the study conducted by (Jarrousse et al., 2006) in which MF skin showed a strong intensity of labelling with TLR2, TLR4, TLR9 in the epidermis.

The aim of this work is to study expression of TLR6 in tissue and serum of patients with MF in comparison with controls, in an attempt to elucidate its role in the pathogenesis of MF.

\section{PATIENTS AND METHODS}

Permission to conduct the study was obtained from the Ethical Committee of Fayoum University. An informed consent was obtained from participants who accept to participate in the study.
This was a case-control study which included 48 participants, 33 patients with MF and 15 healthy controls who were collected from Dermatology, STDs and Andrology Department of Fayoum University Hospital (Fayoum, Egypt) and Al-Haud Al-Marsoud hospital (Cairo, Egypt).

Diagnosis was made clinically and confirmed by skin biopsy. Any patient presented by any stage of MF was included. Patients presented by chronic inflammatory diseases, coexistent cutaneous or internal malignancy, infectious skin diseases, MF patients on continuous treatment for an uninterrupted duration by a minimum of 6 months or history of previously treated malignant tumors were excluded.

All patients underwent detailed history taking and clinical assessment of the type of lesions (patch, plaque, and tumor), and extent of lesions according to their anatomical distribution. Serum and tissue samples were collected from both groups to assess level of TLR6. 


\section{RESULTS}

1. This study showed that there is a highly statistically significant difference with p-value < 0.001 between case group and control group regarding serum level of TLR6.

\begin{tabular}{|c|c|c|c|c|}
\hline \multirow{2}{*}{ Variable } & \multicolumn{2}{|c|}{ Groups } & t test & p value \\
\cline { 2 - 4 } & Case & Control & & \\
\hline $\begin{array}{c}\text { Serum TLR-6 } \\
(\mathrm{pg} / \mathrm{ml})\end{array}$ & $152.33 \pm 34.45$ & $390.71 \pm 65.27$ & 16.618 & $0.000^{\mathrm{HS}}$ \\
\hline
\end{tabular}

\section{Serum TLR-6 (pg/ml)}
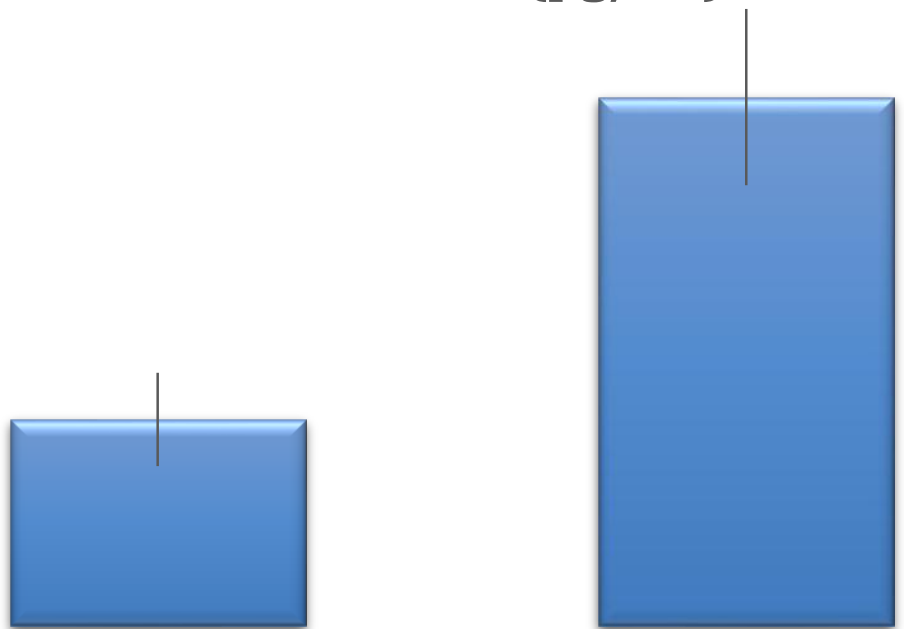

2. This study also revealed that there is a highly statistically significant difference with p-value < 0.001 between case group and control group regarding tissue TLR6.

\begin{tabular}{|c|c|c|c|c|}
\hline \multirow{2}{*}{ Variable } & \multicolumn{2}{|c|}{ Groups } & t test & p value \\
\cline { 2 - 3 } & Case & Control & \\
\hline $\begin{array}{c}\text { Tissue TLR6 } \\
(\mathrm{pg} / \mathrm{mg})\end{array}$ & $61.49 \pm 12.80$ & $93.16 \pm 7.07$ & 8.947 & $0.001^{\mathrm{HS}}$ \\
\hline
\end{tabular}




\section{Tissue TLR6 (pg/mg)}
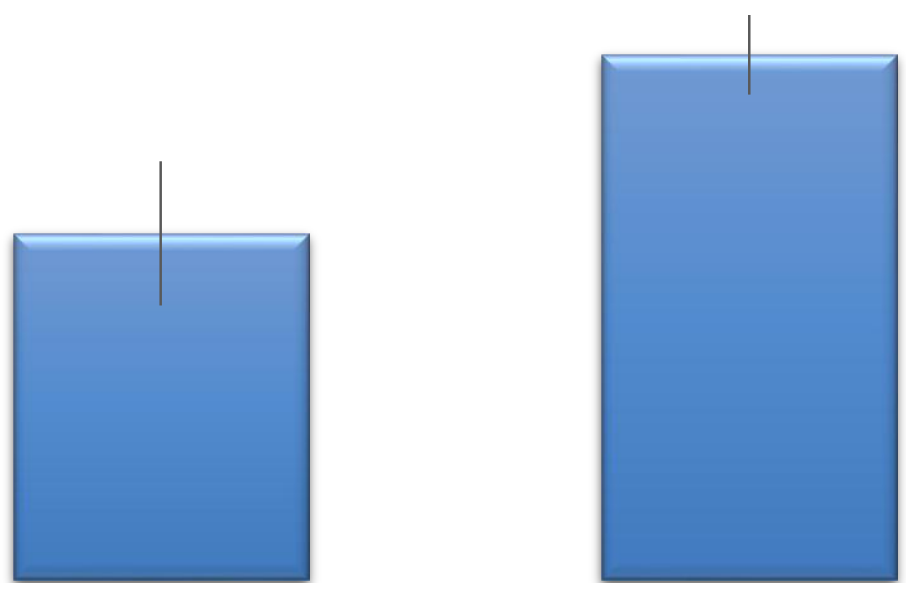

2. The present study showed that there is a statistically significant positive correlation between tissue TLR6 and stage with p-value $<0.05$ and there is no statistically significant correlation with age, sex, duration and type with $\mathrm{p}$-value $>0.05$.

\begin{tabular}{|c|c|c|c|}
\hline \multirow{2}{*}{ Variable } & \multicolumn{3}{|c|}{ Tissue TLR6 } \\
\cline { 2 - 4 } & $\begin{array}{c}\text { Pearson } \\
\text { Correlation }\end{array}$ & $\mathrm{p}$ value & Significant \\
\hline Age & 0.003 & 0.987 & Non significant \\
\hline sex & -0.07 & 0.699 & Non significant \\
\hline Duration & -0.059 & 0.742 & Non significant \\
\hline type & -0.144 & 0.424 & Non significant \\
\hline Stage & 0.566 & 0.001 & Significant \\
\hline
\end{tabular}

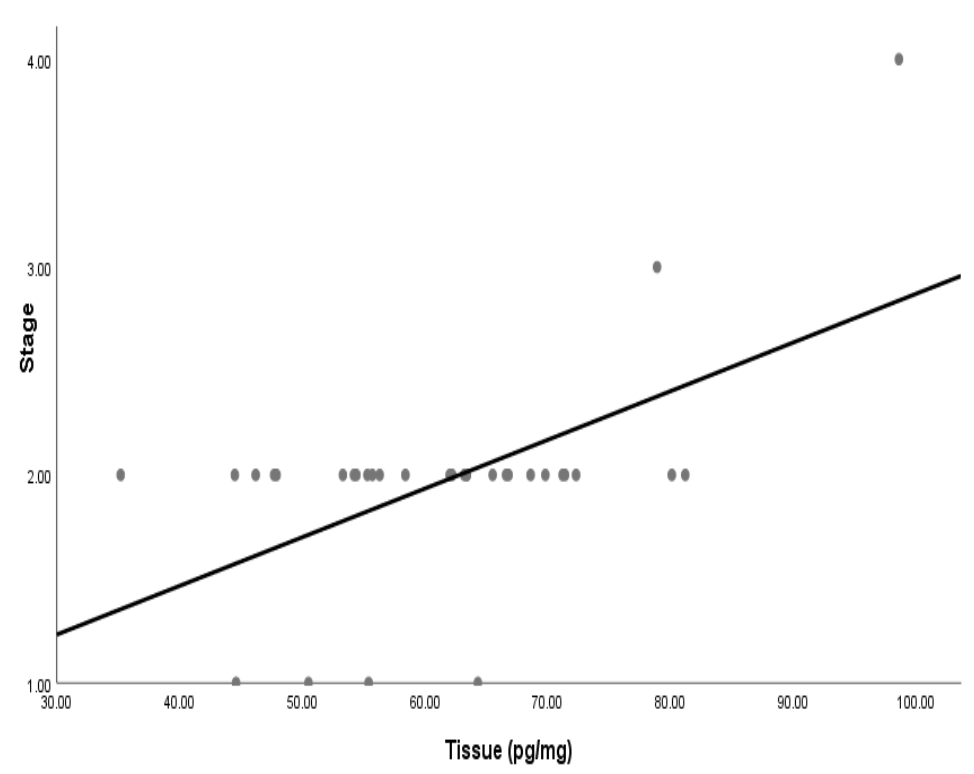




\section{Discussion}

Skin microenvironment plays a crucial supporting role in MF [6]. Toll like receptors are one of pattern recognition receptors that function as surface transmembrane receptors and permit cells to recognize self from nonself in immune activation. Consequently, in the last two decades mounting evidence has inextricably linked TLR activation with the pathogenesis of immune diseases and cancer [7].

\section{[1]}

Tissue TLR6 level was lower in MF cases than in controls and the difference was highly statistically significant with $\mathrm{p}$ value < 0.001. Comparing the tissue TLR6 levels in[2] relation to $\mathrm{MF}$ staging revealed the lowest mean value in stage $\mathrm{Ib}$ and highest mean value in stage IIb.

Kado et al., 2012 observed that TLR6[3] staining was increased in epidermis, endothelial cell lining and tumor infiltrate compared with controls. Similar to our present study independent patient cases with disease progression from patch to plaque or nodular stage did exhibit increased intensity of TLR6 in epidermis, endothelial cell lining and tumor infiltrate .This increased staining of tumor infiltrate is particularly interesting in tumor stage as these lymphocytes are thought to represent primarily malignant cells.

However, the study conducted by Kado et al., 2012 included only 8 patients but the present study included larger scale of patients including age and sex of the patients and type and duration of MF.

\section{Conclusion}

To our knowledge, this is the first study to assess the serum and tissue levels of TLR 6 in MF and to prove that serum and tissue TLR6 is decreased in MF and to prove that tissue TLR6 levels correlated positively with the stage of MF, suggesting that tissue TLR6 level could be a possible prognostic factor in MF.
In conclusion, the current study sheds the light on the possible role of TLR6 as a prognostic factor in MF, and also provides an insight about the possible role of TLR6 in the pathogenesis of $\mathrm{MF}$, which offers better options for MF management.

\section{References}

] Ermertcan AT, Öztürk F and Gündüz K (2011): Toll-like receptors and skin. Journal of the European Academy of Dermatology and Venereology; 25: 997-1006.

Lim KH and Staudt LM (2013): Toll-Like Receptor Signaling. Cold Spring Harb Perspect Biol; 5(1): a011247.

Pimpinelli N, Olsen EA, Santucci M, et al. (2005): Defining early mycosis fungoides. $J$ Am Acad Dermatol; 53: 1053-1063.

[4] Willemze R, Hodak, E, Zinzani, PL, Specht $L$ and Ladetto $M$ (2013). Primary cutaneous lymphomas: ESMO Clinical Practice Guidelines for diagnosis, treatment and follow-up. Annals of Oncology; 24: 149154

[5] Petry V and Gaspari AA (2009): Toll-like receptors and dermatology. International Journal of Dermatology; 48: 558-570.

[6] Jawed SI, Myskowski, PL, Horwitz , Moskowitz A and Querfeld C (2014): Primary cutaneous T-cell lymphoma (mycosis fungoides and Sézary syndrome): part II. Prognosis, management, and future directions. J. Am. Acad. Dermatol; 70, 223.e1-17; quiz 240-242.

[7] Dowling JK and Mansell A (2016): Tolllike receptors: the swiss army knife of immunity and vaccine development. Clin Transl Immunology; 5: e85. 
[8] Jarrousse V, Quereux G, Knol AC, Khammari A and Dreno B. (2006): Toll-like receptors 2, 4 and 9 expression in cutaneous T- cell lymphoma (mycosis fungoides and sezary syndrome). Eur $J$ Dermatol; 16: 636-641.

[9] Kado JA, Shango M, Mehregan C and Mehregan DR (2012): Mapping Toll- like receptor activity in different stages of cutaneous T-cell lymphoma. Am $J$ Dermatopathol; 34: 691-698.
[10] Tawdy AME, Amin IM, Hay RMA, Hassan AS, Gad ZS and Rashed LA (2017): Toll-like receptor (TLR)7 expression in mycosis fungoides and psoriasis: a casecontrol study. Clinical and Experimental Dermatology; 42: 172-177. 